\title{
The Comprehensive Evaluation Method of Fuzhou Residents' Happiness Index System Construction
}

\author{
Tianfu Lin \\ School of Minjiang University, Fuzhou 350108, China
}

\begin{abstract}
Keywords: The Comprehensive Evaluation Method, People's Happiness Index, Fuzhou.
\end{abstract}
\begin{abstract}
As an important index to measure and evaluate residents' quality of life, People's Happiness Index gains new emphasis with the improvement of our social economy. The paper summarized and analyzed on the base of the existing domestic and foreign research, the originality of the proposed comprehensive evaluation method based on the Fuzhou city resident's happiness index, to fill the gaps in research on happiness index in Fuzhou, to vigorously carry out the construction of happy Fuzhou has certain reference significance.
\end{abstract}

\section{Introduction}

In order to enhance people's sense of happiness, the governments, research institutions and scholars have paid a lot of effort all over the world. However, the sense of happiness is always a subjective concept, happiness index as a quantitative indicator is necessary to study people's sense of happiness scientifically. In 2006, 'the sense of happiness' that reflects the subjective feeling was listed into Chinese' evaluation system of a harmonious society 'for the first time, the ultimate goal of the construction of happiness index that can improve social welfare and people's livelihood is to maximize the sense of happiness of people.In order to achieve this goal, the prerequisite is to establish a comprehensive and scientific indicator system of happiness index to measure people's happiness level , and realize its function of monitoring, diagnosis and guiding effectively. It is necessary to conduct a systematic and in-depth reflection on the overall trend of the development of the society, and put forward a continuous, constructive and even fundamental systematic solution, if the comprehensive numerical value of indicator system show a trend that the social and economic development indicators is opposite with people's happiness index, and at this time the practical operation of this function is reflected. Therefore, the construction of reasonable, scientific and effective indicator system of happiness index of Fuzhou as a prerequisite to be put on the agenda.

\section{A review of the existing indicator system of happiness index}

The scientific practice should be established on the basis of scientific theory, it is necessary to build Fuzhou characteristics of indicator system of happiness index on the basis of the reality of the fuzhou, and analy the existing research results and social practice comprehensively, scientifically and judiciously, and then on this basis, the paper puts forward the corresponding indicator system of happiness index of Fuzhou. On the whole, the scholars who study the index of happiness in China mainly focus on the theoretical research on the construction of the indicator system of happiness index, which can be divided into three categories:

The first is the subjective evaluation method through questionnaire and interview. Its typical representative is Xing Zhanjun. As a leading figure in the study of happiness index in China, Xing Zhanjun etc., after a lot of investigation, interviews, sorting, collecting all kinds of research data, believe that on the background of current social development level, the 10 core aspects that constraint the Chinese people's hhappiness index are: Abundant content experience index, Mental health experience index, Growth experience index, Social confidence experience index, Target value experience index, Self-acceptance experience index, Interpersonal adaptation experience index, Physical health experience index, Psychological equilibrium experience index, Family atmosphere 
experience index, and then compiled "Chinese People's Subjective Well-being Scale" according to those indexes which consists of 40 items to measure those indexes. ${ }^{[1]}$ In the process of practicing 'harmonious Shenzhen' social investigation and evaluation, it is divided into three types of indicators to measure the sense of happiness of residents. Class A: relates to the life satisfaction of the cognitive category, including the satisfaction of living conditions (such as employment, income, social security, etc.), the satisfaction of quality of life (such as living conditions, health status, education status, etc.).Class B: involves the mentality of emotion category and the level of emotional happiness, including the degree of mental stress, mentality and so on. Class C: the harmony of personal and the harmony between individual and social.

The second is objective evaluation method by using objective statistical indicators which calculate by formula. The typical representative is Lin Fengqi.He pointed out,in "The new ruler-- national happiness index",that GNH contains the indexes to measure individual and collective welfare, which can supplement and correct the deficiencies and defects of GDP effectively.GNH is the total value of social happiness, we can use a way of transmission and substitution to define happiness from the perspective of social health, welfare, civilization and environmental protection, and then happiness is measured indirectly by setting some relevant social indicators. GNH accounting system composed by the following formula: GNH= GDP index $* \mathrm{a} \%+$ social health index $* \mathrm{~b} \%+$ social welfare index $* \mathrm{c} \%$ + social civilization index $* \mathrm{~d} \%+$ ecological environment index $* \mathrm{e} \%$ ( $\mathrm{a}, \mathrm{b}, \mathrm{c}, \mathrm{d}, \mathrm{e}$ respectively represent the weightings of GDP index, social health index, social welfare index, social civilization index and ecological environment index, the value of specific weight depends on the economic and social goals that the government wanted). ${ }^{[2]}$ Corresponding to this, "Index Composition and Calculation Method of National Happiness Index Accounting System "published by Zhejiang Province, in which the index consists of five categories: GDP index, social health index, social welfare index, social civilization index, ecological environment index, and which are similar to social construction indicators. According to the related research of happiness we can find that education, employment, income, social security, health care, social management and so on directly affect people's happiness.

The third is the subjective and objective evaluation method. The representative views are: Qian Xuefei pointed out, in "The Method to Combine Composite Indicator and Sub-index to Measure the Residents' Happiness Index", that there are two main disadvantages in the measurement of existing happiness index, which are unstable foundation and strong subjectivity, it is necessary to refer to the reasonable elements of the single observation of happiness index, and then compose comprehensive indicator of happiness index with happiness score.According to Maslow's hierarchy of needs theory,the paper compose the happiness index with 5 first class indicators and 23 second class indicators, and the 5 first class indicators are :happiness index of Physiological needs, happiness index of Safety needs, happiness index of Social needs, happiness index of Esteem needs and happiness index of Self-actualization needs. It is believed that the Measurement of People's Happiness Index with Combination of Centralization and Decentralization has its unique advantages and functions. ${ }^{[3]}$ The specific application of the theory in practice is :on October 11, 2006, "the comprehensive evaluation indicator system of happy Jiangyin" officially released which be used to measure the sense of happiness of Jiangyin people. The system has more than 50 indicators, objective indicators weights $60 \%$ and subjective indicators weights $40 \%$.

By studying the existing theory and practice, we can see that the measurement of happiness index has always been controversial, including the basis of measurement, and weather suitable to certain people maximized and so on. It is a three-dimensional complex research topic, and its perspective integrates economics, sociology, psychology, statistics and other related disciplines.Through comparative analysis, we believe that the measure method of pure subjective index can reflect the sense of happiness from the micro, but the reliability of survey results may be influenced seriously by respondents' mood and deviation in the understanding of happiness and other factors, because those factors are very subjective. However, the measurement method of the pure objective index can objectively measure the happiness index of a region, but it cannot fully reflect the actual situation of the 
region. As Zhang Jin,Planning statistics PhD students, Xiamen University, pointed out in "National happiness index: a new evaluation scale of social development": because happiness index is based on individual will, the individual's outlook on life and values, which are determined by cultural education, religious belief, gene, personality, age, gender and other objective conditions, will also affect people's happiness. While, the subjective and objective index system based on the comprehensive evaluation method can make up for the shortcomings of the former two methods ${ }^{[4]}$.In conclusion, although from all walks of life without much controversy to the subjective feelings, which presents obvious individual differences and hard to compare, the relative homogeneity of people's basic needs are inherently determine that happiness should be an objective quantitative indicator. This has laid a practical foundation for the establishment of the indicator system model of Fuzhou happiness index.

\section{The principle of the construction of indicator system of Fuzhou residents' happiness index}

The existing theoretical and practical analysis shows that it's difficult to get a unified standard for indicator system of resident's happiness index which based on different value orientations. The academic circles have been exploring the construction of a set of compatible, relatively uniform and perfect indicator system, but the research group believes that the difference of construction of different indicator system is the inevitable result, when take the true situation of each region into consideration, and it is the difference highlights its uniqueness. In practice, no matter how many differences between the various versions of the indicator system, all parties emphasize that the measurement of happiness index is a systematic project involving many factors and aspects. The evaluation and assessment to the happiness index is not a single indicator or some indicators can be completed, we must summarize the various aspects of people's happiness and the more detailed the category, the better it will be. Considering the feasibility of implementation and other reasons, all kinds of factors should be filtrated in the progress of constructing indicator system. Overall, the indicator system of Fuzhou residents' happiness index should be designed according to the following principles:

(1)Completeness. To comprehensively analyze all aspects of people's lives, with the perspective of system fully analyzes the factors influencing happiness. It is impossible to completely summarize all aspects, but as far as possible perfection, important factors can not be lacking.

(2)Independence.Each influence factor should be independent. Which means each factor should have their own clear and independent meaning, should not be mutually cross covered, in order to avoid repeated measurement.

(3)Operability. The data should be operated in the index system, that is, the data can be easily obtained from the statistical department, otherwise it will lose its practical significance.

(4)Universality .The object of happiness index is the majority of people,different individuals have different influence factors, but the happiness index should be based on the factors that affect the vast majority of people's happiness, in order to make sure that the overall representation and applicability of index.

(5)Pertinence. With the change of the region and time, the structure of the project should be adjusted to adapt to different objects, and improve the accuracy of the measurement.

\section{The construction of indicator system of Fuzhou peoples' happiness index}

Based on the above principle, the research group takes the true situation of Fuzhou into consideration, and draw lessons from Pingdingshan of Henan happiness index which focuses on the performance evaluation and Guangdong happiness index system which is based on the comprehensive consideration of the economic and social livelihood. At the same time, group focuses on the recommendations of experts and professors from Fuzhou University and Fujian Normal University, and then this paper puts forward the indicator system model of Fuzhou residents' happiness index based on the comprehensive evaluation method.(Tab.1: Objective happiness index consist of economic situation, political situation, social status, health status, environmental conditions, cultural conditions ; subjective happiness index consist of 20 subjective indicators) 
Tab.1 The indicator system of Fuzhou peoples' happiness index and the weight

\begin{tabular}{|c|c|c|c|c|c|}
\hline \multirow{30}{*}{$\begin{array}{l}\text { The } \\
\text { indicator } \\
\text { system of } \\
\text { Fuzhou } \\
\text { people's } \\
\text { happiness } \\
\text { index }\end{array}$} & $\begin{array}{l}\text { first grade } \\
\text { indexes and } \\
\text { weight }\end{array}$ & $\begin{array}{l}\text { second grade } \\
\text { indexes and } \\
\text { weight }\end{array}$ & third grade indexes & $\begin{array}{c}\text { unit of } \\
\text { measurement }\end{array}$ & weight \\
\hline & \multirow{22}{*}{$\begin{array}{l}\text { Objective } \\
\text { index } \\
\text { system } 60 \%\end{array}$} & \multirow{6}{*}{$\begin{array}{l}\text { Economic } \\
\text { situation } \\
38 \%\end{array}$} & GDP per capita & yuan & 18.53 \\
\hline & & & $\begin{array}{l}\text { Per capita disposable income of } \\
\text { urban residents }\end{array}$ & yuan & 18.03 \\
\hline & & & Urban unemployment rate & $\%$ & 16.03 \\
\hline & & & Engel coefficient of urban residents & $\%$ & 9.75 \\
\hline & & & $\mathrm{CPI}$ & $\%$ & 18.85 \\
\hline & & & $\begin{array}{l}\text { Per capita existing housing area of } \\
\text { urban residents }\end{array}$ & $\mathrm{m} 2$ & 18.8 \\
\hline & & \multirow{2}{*}{$\begin{array}{l}\text { Political situation } \\
\qquad 15 \%\end{array}$} & $\begin{array}{l}\text { Administrative efficiency and } \\
\text { effective complaint completion rate }\end{array}$ & $\%$ & 50 \\
\hline & & & $\begin{array}{l}\text { Petition cases scheduled completion } \\
\text { rate }\end{array}$ & $\%$ & 50 \\
\hline & & \multirow{4}{*}{$\begin{array}{l}\text { Social situation } \\
17 \%\end{array}$} & $\begin{array}{c}\text { Endowment insurance, medical } \\
\text { insurance, unemployment insurance } \\
\text { number of insured persons }\end{array}$ & $\begin{array}{l}\text { ten thousand } \\
\text { people }\end{array}$ & 26.31 \\
\hline & & & $\begin{array}{l}\text { Safety accident death toll of per } \\
\text { million yuan GDP }\end{array}$ & person & 28.39 \\
\hline & & & $\begin{array}{l}\text { Industrial and mining, trade and } \\
\text { employment deaths of per 100,000 } \\
\text { people }\end{array}$ & person & 17.48 \\
\hline & & & $\begin{array}{c}\text { Road traffic deaths of per } 10000 \\
\text { people }\end{array}$ & person & 27.82 \\
\hline & & \multirow{3}{*}{$\begin{array}{l}\text { Health situation } \\
\qquad 10 \%\end{array}$} & $\begin{array}{l}\text { Number of professional doctors of } \\
\text { per } 1000 \text { people }\end{array}$ & $\%$ & 33.63 \\
\hline & & & Infectious disease mortality rate & $\begin{array}{l}\text { Hundred } \\
\text { thousandth }\end{array}$ & 32.29 \\
\hline & & & $\begin{array}{c}\text { Diagnosis and treatment of various } \\
\text { medical institutions }\end{array}$ & Person & 34.08 \\
\hline & & \multirow{4}{*}{$\begin{array}{l}\text { Environmental } \\
\text { condition } \\
10 \%\end{array}$} & Forest cover rate & $\%$ & 24.89 \\
\hline & & & Urban per capita park area & $\%$ & 24.63 \\
\hline & & & $\begin{array}{c}\text { Comprehensive energy consumption } \\
\text { of } 10000 \text { yuan GDP }\end{array}$ & EZZ & 26.33 \\
\hline & & & $\begin{array}{l}\text { Water function area water quality } \\
\text { compliance rate }\end{array}$ & $\%$ & 24.14 \\
\hline & & \multirow{3}{*}{$\begin{array}{l}\text { Cultural situation } \\
10 \%\end{array}$} & $\begin{array}{l}\text { Enrollment rate of school-age } \\
\text { population in compulsory education }\end{array}$ & $\%$ & 30.51 \\
\hline & & & $\begin{array}{l}\text { High school education gross } \\
\text { enrollment rate }\end{array}$ & $\%$ & 37.24 \\
\hline & & & $\begin{array}{l}\text { The area of public cultural facilities of } \\
\text { per } 10000 \text { people }\end{array}$ & $\mathrm{m} 2$ & 32.25 \\
\hline & \multirow{7}{*}{$\begin{array}{l}\text { Subjective } \\
\text { index } \\
40 \%\end{array}$} & & income satisfaction & & 0.0513 \\
\hline & & & career satisfaction & & 0.0581 \\
\hline & & & Career satisfaction & & 0.0606 \\
\hline & & & Development opportunity satisfaction & & 0.0482 \\
\hline & & & Housing satisfaction & & 0.0479 \\
\hline & & & $\begin{array}{c}\text { Commercial housing price } \\
\text { satisfaction }\end{array}$ & & 0.0536 \\
\hline & & & Residential environment satisfaction & & 0.0545 \\
\hline
\end{tabular}




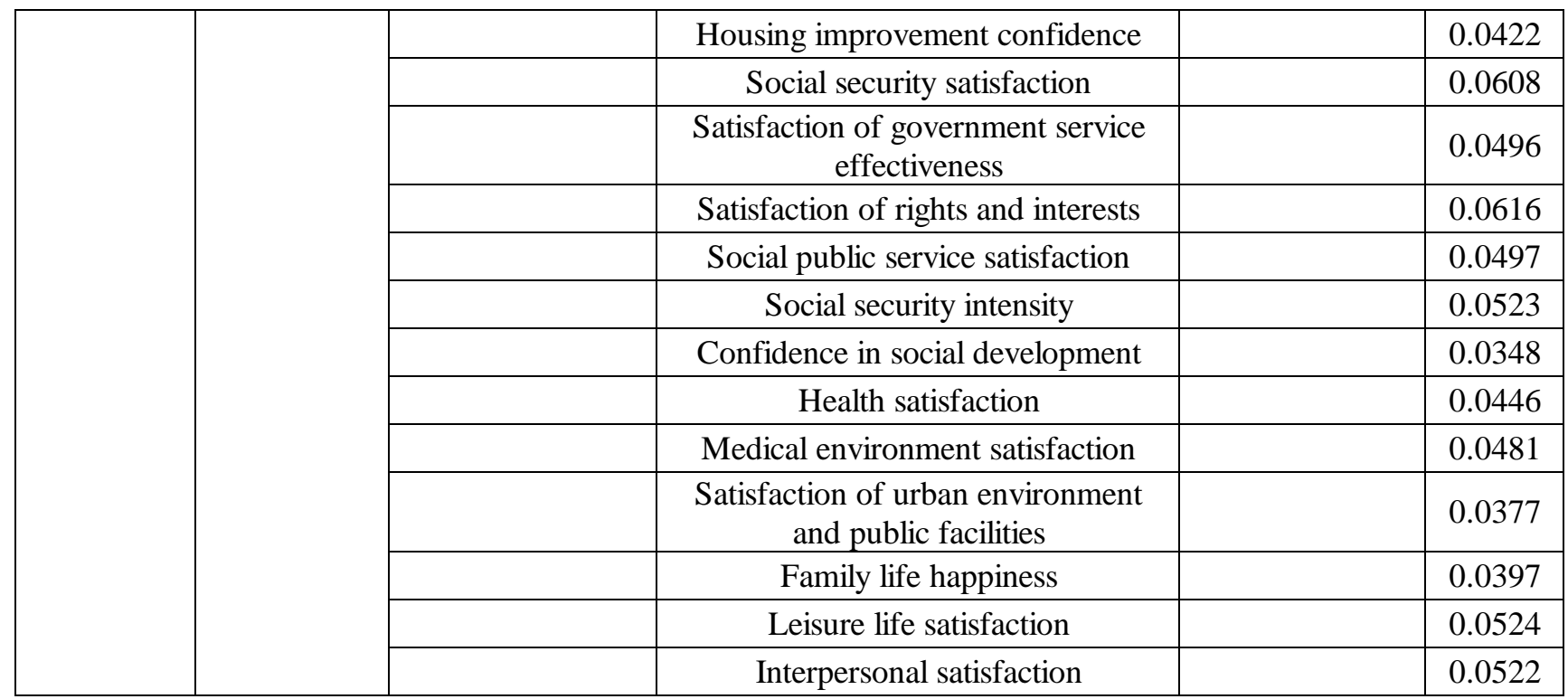

\section{The overview of weight and calculation of the indicator system of Fuzhou people's happiness index}

Through consulting the data and consulting the relevant agencies and departments, the research group obtained the objective index value of Fuzhou city from 2006 to 2016, and the subjective index value was obtained by questionnaire survey.On this basis, waiting for it and then measure the residents' happiness index of Fuzhou according to the comprehensive index method. The idea of comprehensive index method as follows: firstly, quantifying the index of happiness index system; secondly, determining the weight of each index in the whole system according to the factor analysis method; finally, according to the importance of every index synthesize happiness index. The specific formula is: $\mathrm{h}=\sum_{\mathrm{i}=1}^{\mathrm{n}} \beta_{\mathrm{i}} \mathrm{X}_{\mathrm{I}}(\mathrm{h}$ stands for happiness index, $\mathrm{X} 1, \mathrm{X} 2, \ldots \ldots, \mathrm{Xn}$ stands for indexes are contained into indicator system of happiness index, $\beta$ i stands for weight of each index).

The expert weighting method is taken in indicator system of Fuzhou people's happiness index firstly, according to the objective indicators accounted for $60 \%$ and the subjective indicators accounted for $40 \%$ of the weight to weight. According to the experts take the average value, obtained the weight of the objective secondary indicators are as follows: the economic situation accounted for $38 \%$, the political situation accounted for $15 \%$, the social status accounted for $17 \%$, the health status accounted for $10 \%$, the environmental status accounted for $10 \%$, the cultural status accounted for $10 \%$. And then weighting for the objective third grade indicators and the subjective third grade indicators with SPSS16.0 and EXCEL.

\subsection{The weight for the objective third grade indicators}

The first step of the objective third grade indicators is the consistent and dimensionless treatment of the data, in order to eliminate the influence of the original index. The research group uses standardization method to carry on the dimensionless to each objective third grade indicator(the formula is $X_{i j}^{*}=\frac{X_{i j}-\bar{X}_{j}}{S_{j}}$ ), and then analyze objective third grade indicators, finally the Communalities of each index is calculated according to $\mathrm{H}_{\mathrm{i}}^{2}$ (Statistically, Communalities is used to express the variance proportion of common factor, that is the contribution to each variable, its value is the sum of the row elements of the factor load matrix, and it reflects the relative importance of each index) the rotated factor loading matrix and $\beta_{\mathrm{i}}$ (Based on the Communalities of common factors in factor analysis)the weight ., The establishment of Communalities formula is as follows: $\mathrm{H}_{\mathrm{i}}^{2}=\partial_{\mathrm{i} 1}^{2}+\partial_{\mathrm{i} 2}^{2}+\cdots+\partial_{\mathrm{im}}^{2}\left(\mathrm{H}_{\mathrm{i}}^{2}\right.$ stands for Communalities, $\partial_{\mathrm{im}}^{2}$ stands for the contribution of the index $i$ to the common factor $\mathrm{m}$ ). The formula 
of $\beta_{\mathrm{i}}$ (weight)is as follows: $\beta_{\mathrm{i}}=\frac{\mathrm{H}_{\mathrm{i}}^{2}}{\sum_{\mathrm{i}=1}^{\mathrm{n}} \mathrm{H}_{\mathrm{i}}^{2}}\left(\mathrm{H}_{\mathrm{i}}^{2}\right.$ is Communalities in factor analysis). Based on the above principle, the weighting process of economic status is shown in Tab.2 and tab.3:

Tab. 2 The rotated factor loading matrix of economic indicators

\begin{tabular}{|c|c|c|}
\hline Variable & Common factor one & Common factor two \\
\hline GDP per capita & 0.979 & -0.032 \\
\hline Per capita disposable income of urban residents & 0.966 & -0.025 \\
\hline Urban unemployment rate & -0.88 & -0.236 \\
\hline Engel coefficient of urban residents & -0.708 & -0.06 \\
\hline CPI & 0.005 & 0.988 \\
\hline Per capita existing housing area of urban residents & 0.954 & -0.252 \\
\hline
\end{tabular}

Tab.3 The Communalities and weight of economic indicators

\begin{tabular}{|c|c|c|}
\hline Variable & Communalities & Weight (\%) \\
\hline GDP per capita & 0.959465 & 18.53 \\
\hline Per capita disposable income of urban residents & 0.933781 & 18.03 \\
\hline Urban unemployment rate & 0.830096 & 16.03 \\
\hline Engel coefficient of urban residents & 0.504864 & 9.75 \\
\hline CPI & 0.976169 & 18.85 \\
\hline Per capita existing housing area of urban residents & 0.97362 & 18.80 \\
\hline
\end{tabular}

According to the above method, the corresponding weights of other objective third grade indicators can be obtained as shown in Tab.1.

\subsection{The weight to subjective third grade indicators}

For the weight to subjective indicators, the method used by the research group, which is the use of software SPSS 16 for data factor analysis, to determine the weight of each index.First of all, the original data were tested by KMO, and the results were as Tab.4.

Tab.4 KMO and Bartlett's Test

\begin{tabular}{|l|c|c|}
\hline \multicolumn{2}{|c|}{ Kaiser-Meyer-Olkin Measure of Sampling Adequacy. } & .829 \\
\hline \multirow{3}{*}{ Bartlett's Test of Sphericity } & Approx. Chi-Square & 2.25913 \\
\cline { 2 - 3 } & Df & 190 \\
\cline { 2 - 3 } & Sig. & .000 \\
\hline
\end{tabular}

The KMO index is one of the effective indexes for factor analysis.According to the results of KMO and Bartlett tests in table 4:the KMO statistic is 0.829 ,there is a high degree of overlap between the variables, and the effect of factor analysis is good. The value of $\mathrm{P}$ is 0.000 , reject independence hypothesis, the correlation between the variables is strong. Therefore, the test of applicability of factor analysis is passed.

After the test, factor analysis is given in Tab.5(Tab.5 is the matrix table after factor rotation), from this we can calculate the Communalities. The Communalities can express the variance ratio of $x_{i}$, the common explanatory variable of $f_{1}, f_{2} \ldots \ldots f_{m}$ (common factor), that is, the sum of the contribution of $f_{m}$ two variables, its value is the sum of squares of the row elements in the factor load matrix, it reflects the importance of the corresponding items to the evaluation concept, that is the importance of evaluation index, it considers the common role of all common factors. 
Tab.5 Rotated Component Matrix

\begin{tabular}{|c|c|c|c|c|c|}
\hline & \multicolumn{5}{|c|}{ Component } \\
\hline & 1 & 2 & 3 & 4 & 5 \\
\hline Rights protection & .824 & .151 & & & .111 \\
\hline Social security & .806 & .121 & .175 & & .102 \\
\hline $\begin{array}{l}\text { Government service } \\
\text { Effectiveness }\end{array}$ & .714 & .225 & & .120 & \\
\hline Social public service & .701 & & & & .292 \\
\hline Social development & .360 & .199 & .229 & .336 & .263 \\
\hline Cause & .160 & .811 & & .138 & \\
\hline Occupation & & .794 & .166 & .123 & \\
\hline Income & .170 & .741 & & & .129 \\
\hline $\begin{array}{l}\text { Development } \\
\text { Opportunities }\end{array}$ & .239 & .689 & & .164 & \\
\hline Residential environment & & & .781 & .148 & \\
\hline Commercial housing price & & .146 & .745 & .212 & \\
\hline Housing improvement & & .163 & -.626 & .266 & \\
\hline $\begin{array}{l}\text { Urban environment and } \\
\text { Public facilities }\end{array}$ & .171 & & .601 & & .215 \\
\hline Housing & & .396 & .579 & .251 & \\
\hline $\begin{array}{l}\text { Interpersonal } \\
\text { Communication }\end{array}$ & .112 & .118 & & .761 & \\
\hline Amateur life & & & & .734 & .263 \\
\hline Family life & .142 & .178 & .174 & .615 & \\
\hline Sense of security & & .229 & .184 & -.115 & .712 \\
\hline Good health & & & & .245 & .676 \\
\hline Medical environment & .364 & & .106 & .262 & .588 \\
\hline
\end{tabular}

Communalities is the degree that the original information contained in each variable can be represented by common factor. Calculating $\beta_{\mathrm{i}}$, the weight, by factor analysis , and the concept of Communalities in factor analysis is the key to measure the weight of indexes, its formula is $\beta_{i}=\frac{H_{i}^{2}}{\sum_{i=1}^{n} H_{i}^{2}}$ $\left(\mathrm{H}_{\mathrm{i}}^{2}\right.$ is the Communalities of factor analysis), when get the Communalities, we calculate the weight of the subjective third grade indicators according to formula. The Communalities and weight of the subjective third grade indicators are shown in Tab.6.

Tab.6 The subjective third grade indexes of the Communalities and Weight

\begin{tabular}{|c|c|c|}
\hline Indexes & Communalities & Weight \\
\hline Rights protection & 0.7141 & 0.0616 \\
\hline Social security & 0.7053 & 0.0608 \\
\hline Government service effectiveness & 0.5748 & 0.0496 \\
\hline Social public service & 0.5767 & 0.0497 \\
\hline Social development & 0.4037 & 0.0348 \\
\hline Cause & 0.7024 & 0.0606 \\
\hline Occupation & 0.6731 & 0.0581 \\
\hline Income & 0.5946 & 0.0513 \\
\hline Development opportunities & 0.5587 & 0.0482 \\
\hline
\end{tabular}




\begin{tabular}{|c|l|l|}
\hline Residential environment & 0.6319 & 0.0545 \\
\hline Commercial housing price & 0.6213 & 0.0536 \\
\hline Housing improvement & 0.4892 & 0.0422 \\
\hline Urban environment and public facilities & 0.4367 & 0.0377 \\
\hline Housing & 0.5551 & 0.0479 \\
\hline Interpersonal communication & 0.6056 & 0.0522 \\
\hline Amateur life & 0.6079 & 0.0524 \\
\hline Family life & 0.4603 & 0.0397 \\
\hline Sense of security & 0.6065 & 0.0523 \\
\hline Good health & 0.5170 & 0.0446 \\
\hline Medical environment & 0.5581 & 0.0481 \\
\hline
\end{tabular}

\section{Conclusion}

The research group believes that the indicator system of Fuzhou people's happiness index comprehensively covers all the factors related to happiness, which based on comprehensive evaluation method.Compared to other index system, personality and innovation of the indicator system is reflected in: first, the existing domestic indicator system of happiness indexes almost take unitary analysis (subjective or objective) to calculate it,while the indicator system of Fuzhou people's happiness index takes binary subjective and objective comprehensive analysis to calculate the value, and it is more scientific and rigorous.second, the existing indicator system of happiness index almost ignored the political situation, while Fuzhou indicator system lists political situation separately (And take indicator of effective complaint of administrative efficiency and indicator of letters and visits on schedule for the availability of data ),to make up for some deficiencies of other city indicator system. The research group believes that the research and monitoring of the indicator system of happiness index can provide a reference for the government's public policy, can analyze the influencing factors of people's happiness, can provide choices to social management and then improve the effectiveness and quality of social management .Therefore, in the process of monitoring the indicator system must be based on people's livelihood, supplemented by the index, the principle is focusing on optimizing the effectiveness of governance and play a leading role of index, should not blindly pursue exponential worship. In addition, in order to make the indicator system more scientific and more in line with the requirements of the construction of happy Fuzhou, the indicator system should be adjusted dynamically in the monitoring process of index.

\section{Acknowledgments}

Fund Project: the key issue of Fuzhou municipal Party committee[Rongcheng Committee Office (2011)4th],social sciences seedling project of Minjiang institute, the number of Fund Project: YSY1123.

\section{References}

[1]. Xing Zhanjun,LIU Xiang etc.,"Urban happiness: a report of happiness index from six provincial capitals",Social Science Literature Press,June 2008.

[2]. Lin Fengqi,"The new ruler-- national happiness index",China National Conditions and Strength,no.7,pp.29-31,2006.

[3]. Qian Xuefei, "The Method to Combine Composite Indicator and Sub-index to Measure the Residents' Happiness Index", Journal of Nantong University, Social Science Edition, vol.26,no.3,May 2010. 
[4]. ZhangJin,"National happiness index: a new evaluation scale of social development",Leadership Science,no.15,2006.

[Author's organization]:College of Marxism, Minjiang University, Lin Tianfu, male, born in November 1980, Han nationality, Quanzhou , postgraduate degree, lecturer, research direction: economic sociology, Marx's ideological and Political Education

[Address]:College of Marxism, Minjiang University, No. 518, Wenxian Road, University Town District,Fuzhou City, Fujian Province;Zip code:350108 [Email]: 151667434 @qq.com;[Tel]: 13799977089 